\title{
Morphological dynamics of gully systems in the subhumid Ethiopian Highlands: the Debre Mawi watershed
}

\author{
Assefa D. Zegeye ${ }^{1,2}$, Eddy J. Langendoen ${ }^{3}$, Cathelijne R. Stoof ${ }^{4}$, Seifu A. Tilahun ${ }^{5}$, \\ Dessalegn C. Dagnew ${ }^{5}$, Fasikaw A. Zimale ${ }^{5}$, Christian D. Guzman ${ }^{1}$, Birru Yitaferu ${ }^{2}$, and \\ Tammo S. Steenhuis ${ }^{1,5}$ \\ ${ }^{1}$ Department of Biological and Environmental Engineering, Cornell University, Ithaca, NY, USA \\ ${ }^{2}$ Amhara Region Agricultural Research Institute, Bahir Dar, Ethiopia \\ ${ }^{3}$ US Department of Agriculture, Agricultural Research Service, National Sedimentation Laboratory, Oxford, \\ MS 38655, USA \\ ${ }^{4}$ Soil Geography and Landscape Group, Wageningen University, 6700 AA Wageningen, the Netherlands \\ ${ }^{5}$ School of Civil and Water Resources Engineering, Bahir Dar University, Bahir Dar, Ethiopia
}

Correspondence to: Tammo T. Steenhuis (tss1@ cornell.edu)

Received: 3 March 2016 - Published in SOIL Discuss.: 10 March 2016

Revised: 21 July 2016 - Accepted: 22 July 2016 - Published: 7 September 2016

\begin{abstract}
Gully expansion in the Ethiopian Highlands dissects vital agricultural lands with the eroded materials adversely impacting downstream resources, for example as they accumulate in reservoirs. While gully expansion and rehabilitation have been more extensively researched in the semiarid region of Ethiopia, few studies have been conducted in the (sub)humid region. For that reason, we assessed the severity of gully erosion by measuring the expansion of 13 selected permanent gullies in the subhumid Debre Mawi watershed, $30 \mathrm{~km}$ south of Lake Tana, Ethiopia. In addition, the rate of expansion of the entire drainage network in the watershed was determined using $0.5 \mathrm{~m}$ resolution aerial imagery from flights in 2005 and 2013. About $0.6 \mathrm{Mt}$ (or $127 \mathrm{tha}^{-1} \mathrm{yr}^{-1}$ ) of soil was lost during this period due to actively expanding gullies. The net gully area in the entire watershed increased more than 4-fold from 4.5 ha in 2005 to 20.4 ha in 2013 (>3\% of the watershed area), indicating the growing severity of gully erosion and hence land degradation in the watershed.

Soil losses were caused by upslope migrating gully heads through a combination of gully head collapse and removal of the failed material by runoff. Collapse of gully banks and retreat of headcuts was most severe in locations where elevated groundwater tables saturated gully heads and banks, destabilizing the soils by decreasing the shear strength. Elevated groundwater tables were therefore the most important cause of gully expansion. Additional factors that strongly relate to bank collapse were the height of the gully head and the size of the drainage area. Soil physical properties (e.g., texture and bulk density) only had minor effects.

Conservation practices that address factors controlling erosion are the most effective in protecting gully expansion. These consist of lowering water table and regrading the gully head and sidewalls to reduce the occurrence of gravity-induced mass failures. Planting suitable vegetation on the regraded gully slopes will in addition decrease the risk of bank failure by reducing pore-water pressures and reinforcing the soil. Finally, best management practices that decrease runoff from the catchment will reduce the amount of gully-related sediment loss.
\end{abstract}




\section{Introduction}

Gully erosion is likely the most serious form of land degradation (Poesen et al., 2003). Gullies form because they are an energy-efficient way for runoff to travel from uplands to valley bottoms (Gyssels and Poesen, 2003; Simon et al., 2011). Gullies can contribute more than $90 \%$ of catchment sediment yield (Tebebu et al., 2010; Simon et al., 2011; Zegeye et al., 2014). They have also been found to damage structures and transport routes (Nyssen et al., 2004b; Valentin et al., 2005).

Gullying is a threshold-dependent process controlled by a wide range of factors (Valentin et al., 2005), including rainfall and flowing water, soil properties, and drainage area. Capra et al. (2009) and Campo et al. (2013) found that most of the gully erosion took place during heavy rainfall events - i.e., storm events were one of the drivers for gully erosion. The mechanical actions of the flowing water can result in a rapid mass movement in the gullies by undercutting of the banks (see Fig. 1; Lanckriet et al., 2015). When these mechanical actions at the gully head exceed the cohesive strength of soil, erosion proceeds upslope through a headward cutting gully (Muñoz-Robels et al., 2010). Interactions between such processes are important as hydraulic erosion promotes bank collapse, which then modifies subsequent hydraulic erosion (Thorne, 1990; Avni, 2005). Similarly, gully formation is initiated with the occurrence of convergent shallow subsurface flow that leads to seepage-induced erosion of surface soils, gully heads, and sidewalls (Fig. 1f; Vanmaercke et al., 2016; Tilahun et al., 2013a) as well as sliding (Fig. 1d). Soil saturation by a rising water table decreases the soil shear strength (Poesen, 1993; Langendoen and Simon, 2008) and therefore destabilizes banks (Simon et al., 2000; Langendoen et al., 2013). Active gully networks are therefore predominantly found in the saturated valley bottomlands (Tebebu et al., 2010; Steenhuis et al., 2014), and the deepest and the most spectacular gullies occur in the bottom of the watershed, where, in subhumid monsoonal and wetter climates, the soil becomes saturated starting around the middle of the rain phase and then remain saturated until the end of the rain phase (Tebebu et al., 2014).

Soil properties and soil types also play a role in gully formation and expansion. For example, Vertisols, heavy clay soils with a high proportion of swelling clays (IUSS Working Group WRB, 2015), form deep, wide cracks from the surface downward when they dry out (Fig. 1c) and are prone to the development of pipes (Fig. 1e) that can collapse and thereby turn into large rills or gullies (Valentin et al., 2005; Frankl et al., 2014). This may be one of the reasons that most severe gully areas are often associated with Vertisols (Valentin et al., 2005; Tebebu et al., 2014; Frankl et al., 2014). Similarly, in pasture bottom lands, piping often leads to development of permanent gullies (Jones, 1987; Zegeye et al., 2014). These pipes are part of gully networks, and during the rain phase the infiltrating rainfall discharges through the pipes, which increases the lower soil horizon's vulnerability to erosion.

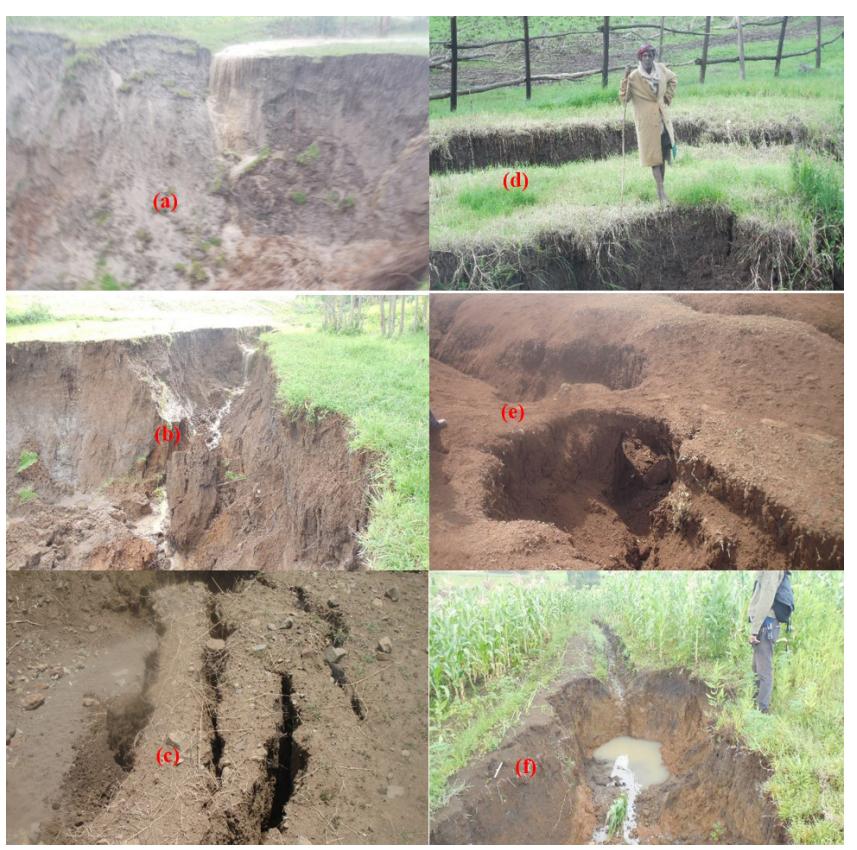

Figure 1. Examples of gully expansion controlled by (a, b) bank geometry (height and slope), (c) tension cracks, (d) landslide, (e) soil pipes, and (f) saturated Vertisols (gully development on conservation ditches, narrow ditch upstream of gully headcut) in the subhumid Debre Mawi (a, b, d, f), Mota (c), and Geregera (e) watersheds (pictures taken in 2013).

The drainage area at the gully head is one of the parameters explaining linear, areal, and volumetric gully headcut retreat (Vandekerckhove et al., 2003; Frankl et al., 2012, 2013b; Vanmaercke et al., 2016). Runoff-contributing drainage area can be used as a surrogate for runoff, especially if it is assumed that the rainfall amount is equal for all drainage areas and that surface conditions and land use are also very similar (Oostwoud Wijdenes and Bryan, 2001). Frankl et al. (2012) reported for the semiarid Tigray region in northern Ethiopia that, among all environmental characteristics in a catchment, only the drainage area had a strong positive association with gully headcut retreat (hereafter, headcut retreat refers to the longitudinal gully growth and bank failure refers to cross-sectional gully growth). Similarly, when data from stable and unstable subcatchments were combined, were stream heads and drainage area of gully (Muñoz-Robles et al., 2010). Nyssen et al. (2002) claimed that increasing the drainage area of the gully head enhances gully development. Additionally, long-term retreat rates often show negativeexponential trends with runoff-contributing area of the gully head, which could be explained by the declining runoffcontributing area of the gully head as it moves upslope (Begin et al., 1980).

Most gully erosion studies in Ethiopia have been carried out in the semiarid Tigray region in northern Ethiopia (e.g., Billi and Dramis, 2003; Nyssen et al., 2006, 2008; Tamene 
et al., 2006; Frankl et al., 2011, 2012, 2013a, b, c). In this region, rehabilitation of gully erosion has been relatively successful (soil loss has been decreased to a range of $1-6 \mathrm{tha}^{-1}$ ) by using check dams and upland soil and water conservation (SWC) measures (Nyssen et al., 2004a, 2006, 2009). Using repeat photographs from 2006 to 2009, Frankl et al. (2011, 2013c) found that about $25 \%$ of the assessed gully sections were stabilized as a result of siltation behind check dams. However, such physical structures have been ineffective in controlling gully erosion in the (sub)humid Ethiopian Highlands, where gullies are formed in saturated Vertisol areas and where water often bypasses the check dams (Dagnew et al., 2015). Importantly, the amount of interflow and surface flow in the humid region is different from that in the arid and semiarid regions (Bayabil et al., 2010; Engda et al., 2011; Tilahun et al., 2013a, b; Steenhuis et al., 2014). Conservation structures that are effective in preventing gullying by overland flow in semiarid regions (Nyssen et al., 2004a, 2006) may not be effective in the humid Ethiopian Highlands regions, where interflow elevates groundwater tables in the valley bottom that promote gully formation and expansion (Tebebu et al., 2010).

Thus, there is a clear need for a better understanding of gully erosion processes and factors in the subhumid Ethiopian Highlands in order to design effective gully control or rehabilitation measures. The objectives of this study were therefore (1) to understand gully erosion processes in the subhumid Ethiopian Highlands and identify factors controlling these processes for effective conservation practices and (2) to provide quantitative estimates of the severity of gully erosion in the subhumid Debre Mawi watershed.

\section{Materials and methods}

\subsection{Description of the study area}

The study area, the Debre Mawi watershed, is located in the subhumid highlands of northwestern Ethiopia, $30 \mathrm{~km}$ south of Bahir Dar along the road to Adet between $11^{\circ} 20^{\prime}$ and $11^{\circ} 22^{\prime} \mathrm{N}$ and $37^{\circ} 24^{\prime}$ and $37^{\circ} 26^{\prime} \mathrm{E}$. The watershed drains an area of 608 ha. The altitude ranges from 2194 to $2362 \mathrm{~m}$ a.s.l.; the elevations of the gullies considered in this study range from 2212 to $2272 \mathrm{~m}$ a.s.l. Rainfall is unimodal with an average value of $1240 \mathrm{~mm} \mathrm{yr}^{-1}$. The majority of the annual rainfall falls between June and the beginning of September and amounts to $900 \mathrm{~mm} \mathrm{yr}^{-1}$. The rainfall gauge station in the Debre Mawi watershed was constructed in 2008 by the Adet Agricultural Research Center to record rainfall in the rain phase only. The dry season lasts between 8 and 9 months. The mean daily temperature is $20^{\circ} \mathrm{C}$.

The hydro-geomorphology of the Debre Mawi watershed is strongly controlled by the geological setting. The lava dykes in the watershed affect the hydrology upslope, forcing subsurface flow to the surface resulting in saturated source areas for surface runoff (Abiy, 2009). Soils are mainly Ni- tisols in the uplands, Vertisols in the bottom slopes, and Regosols on the steep hillslopes. In total, $92 \%$ of the watershed is cultivated, $6 \%$ is rangeland, and the remaining $2 \%$ is mainly covered by eucalyptus trees and shrubs, a small village, and the road linking Bahir Dar with Adet. The small indigenous shrubs are predominantly found on the steep hillslopes.

The soils on the steep slopes $\left(20-30^{\circ}\right)$ in the upper regions are too shallow to sustain crop growth, whereas the less sloping areas in the upper portion of the watershed are predominately cultivated with the major crops: teff (Eragrostis abyssinica), finger millet (Eleusine coracana), maize (Zea mays), and wheat (Triticum aestivum). The mid-slopes of the watershed consist of cropland with mainly teff and some finger millet and maize. Most fields in this area are cropped twice a year. In the main growing season (June-August), farmers primarily cultivate teff and barley (Hordeum vulgare), and after these crops are harvested, they use the residual moisture to cultivate chickpeas (Cicer arietinum), grass pea (Lathyrus sativus), and wheat as secondary crops from September to December. The gently sloping areas $\left(0-6^{\circ}\right)$ contain the periodically saturated bottomlands, which are in pasture and significantly affected by active gully networks. Free grazing is prohibited on most of the grazing lands, particularly on the upper slopes and the valley-bottom areas where the gullies form. The community established bylaws in 2010 to sustain this enclosure, and the farmers started to use a cut-and-carry system to feed their livestock: biomass is now cut on this enclosed part of the watershed and then transported to farms for fodder. This cut-and-carry system is primarily aimed at gully rehabilitation but also used as a best practice to maximize biomass yields for animal feed, although enforcement of the rules is inconsistent.

Here, we focus on the gully processes in the bottomlands and study both the medium-term (8 years, from 2005 to 2013) and short-term (2 years, from 2013 to 2014) gully advancement in the watershed. Specifically, we conducted a comprehensive study of the dynamics of 13 gully headcuts (hereafter referred to as G1 through G13), as well as the factors controlling these dynamics. Gullies G1 and G9 through G13 are located in the central part of the watershed, and gullies G2 through G8 are located at the bottom flat area of the watershed (Fig. 2). All gullies except G11 and part of G6 are situated on communal grazing lands that were enclosed recently.

\subsection{Data collection and analysis}

\subsubsection{Measuring gully widening and headcut retreat during the 2013 and 2014 rain phases}

During the 2013 and 2014 monsoon rain phases, for 13 gullies, we measured (1) the headcut retreat (longitudinal growth) and gully widening (or lateral retreat) $10-30 \mathrm{~m}$ downslope from the headcut and (2) the gully expansion 


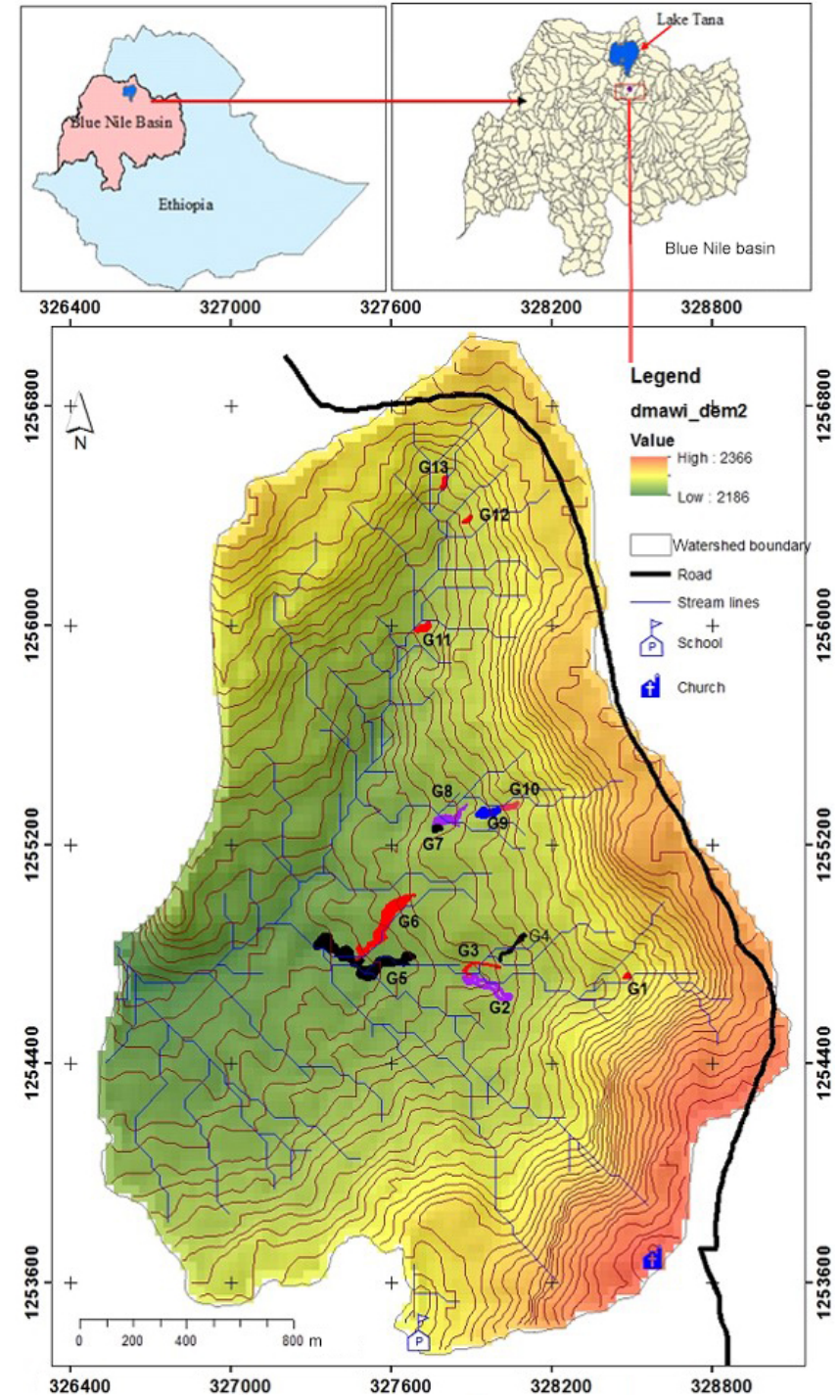

Figure 2. Location of the Debre Mawi watershed within the Blue Nile River basin, Ethiopia (top figures). The watershed map (bottom) shows the contour lines, elevation, streams lines, and the 13 studied gullies (shown in distinct colors and labeled beginning with the letter G). Projected coordinate system: WGS_1984_UTM_Zone_37 N.

rates and associated amount of soil loss along the total gully length.

To measure the headcut retreat and widening of the 13 gullies, we divided the gully downslope of the headcut into three to eight uniform segments. The average distance between two consecutive cross sections was $3.6 \mathrm{~m}$ and varied from 1 to $10 \mathrm{~m}$ with a standard deviation of $2.7 \mathrm{~m}$. This method of measuring the gully dimensions is relatively precise, simple, and low-cost compared with other methods (Casalí et al., 2006, 2015). Gully cross-sectional geometry was surveyed by dividing the cross section into trapezoidal segments at abrupt changes in the ground profile and then measuring the width and depth of the gully at each segment (Fig. 3). Crosssectional area $(A)$ and surface area $(S)$ and volume $(V)$ were then calculated:

$$
\begin{aligned}
& A=\frac{1}{2} \sum_{i=1}^{n-1}\left|\left(w_{i} h_{i+1}-w_{i+1} h_{i}\right)\right|, \\
& S=\sum_{j=1}^{N-1} L_{j}\left(\frac{W_{j}+W_{j+1}}{2}\right), \\
& V=\sum_{j=1}^{N-1} L_{j}\left(\frac{A_{j}+A_{j+1}}{2}\right),
\end{aligned}
$$

where $n$ is the number of trapezoidal segment sides of height $h$ and located a distance $w$ from the left gully edge in a cross section (Fig. 3a), $i$ is a trapezoidal segment index, $W$ is cross section width, $j$ is cross section index, $N$ is number of cross sections, and $L_{j}$ is length of the gully section between cross sections $j$ and $j+1$.

Measurements were carried out repeatedly (about eight times for large gullies to five times for small gullies mainly following large rainstorms and the period between surveys not exceeding 2 weeks) using a tape meter and benchmark pins installed 5 to $10 \mathrm{~m}$ from the gully edges. However, a few gullies expanded more than this distance and the affected pins were reinstalled 5 to $10 \mathrm{~m}$ upslope of the newly formed gully bank.

To estimate gully expansion and the amount of soil loss from the total gully reach, three gully topographic surveys (before and after the rain phases of 2013 and 2014) were conducted. The total soil loss volume over the monitoring period was then obtained by taking the difference in $V_{\mathrm{T}}$ after and before the 2013 and 2014 rain phase. The mass of the soil loss was calculated by multiplying the soil loss volume for each subsection (calculated using Eq. 3) by the measured average bulk density of the soils (see Sect. 3).

The relationships between the change in gully headcut dimensions (lateral, headward, and volumetric erosion) and the controlling factors (daily rainfall, cumulative rainfall, water table, drainage area, headcut height, and soil physical properties such as bulk density and soil texture) were analyzed. Additionally, empirical relationships between the volumetric retreat $(V)$ and the lateral $(W)$ and longitudinal $(L)$ retreat were developed.

\subsubsection{Gully erosion dynamics from 2005 to 2013}

To place the 2-year gully expansion (Sect. 2.2.1) in a broader context, we measured, in addition, the gully dynamics over an 8-year period. Following the approach of Frankl et al. (2013a), we determined the surficial land loss area due to gullying for the Debre Mawi watershed by digitizing all gully edges in Google Earth on aerial imagery from flights on 6 March 2005 and 23 March 2013. This was done for not only the 13 gullies discussed above but for all gullies found 
Table 1. The combined length, area, and volume of the total gully network in the 608 ha Debre Mawi watershed obtained from satellite imagery in 2005 and 2013. The "soil loss" in the last column represents the total soil loss from the gully network preceding the date of measurements and is calculated as the gully volume in the fourth column times the bulk density. Errors were estimated using Eqs. (8) and (9).

\begin{tabular}{lllll}
\hline Year & Gully length, $\mathrm{km}$ & Gully area, ha & Gully volume, $10^{3} \mathrm{~m}^{3}$ & Soil loss, $10^{3} \mathrm{t}$ \\
\hline Observed data in 2005 & 8.7 & 4.5 & 140 & 168 \\
Estimated error in 2005 & & 0.17 & 3.5 & 5 \\
Observed data in 2013 & 26.0 & 20.4 & 654 & 784 \\
Estimated error in 2013 & & 0.4 & 0.87 & 13 \\
Increase from 2005 to 2013 & 17.3 & 15.9 & 514 & 616 \\
Relative change, \%, 2005-2013 & 199 & 350 & 366 & 366 \\
\hline
\end{tabular}
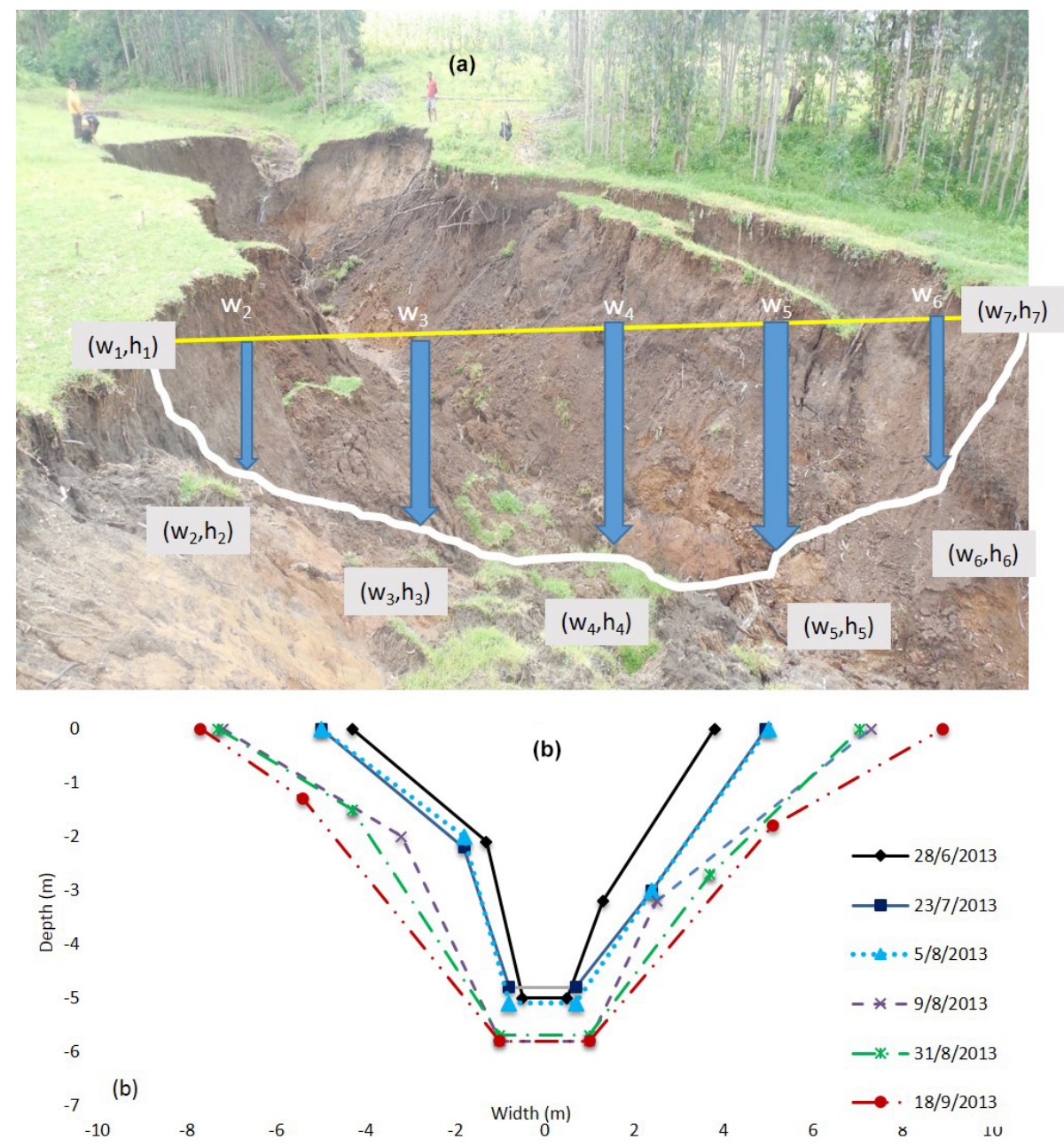

Figure 3. (a) Cross section segmentation methodology to determine the cross-sectional area of the gullies. (b) Measured profiles of a cross section located on gully G6 during the 2013 rain phase, showing the lateral and downward expansion of the gully.

in the watershed (Table 1). The horizontal resolution of the imagery was $0.5 \mathrm{~m}$.

Gullies were digitized by determining the location of each gully in the watershed using a hand-held GPS with a horizontal accuracy of about $3 \mathrm{~m}$ on August 2013, after which its coordinates were imported into Google Earth to situate all gullies on the aerial imagery. The gully edges were then digitized using Google Earth's polygon mapping tool. Finally, the digitized polygons were converted to shape-file format using ESRI's ArcGIS software, which was also used to calculate the surface area and the length of each gully. Since gully volume could not be obtained from aerial measurements, it 


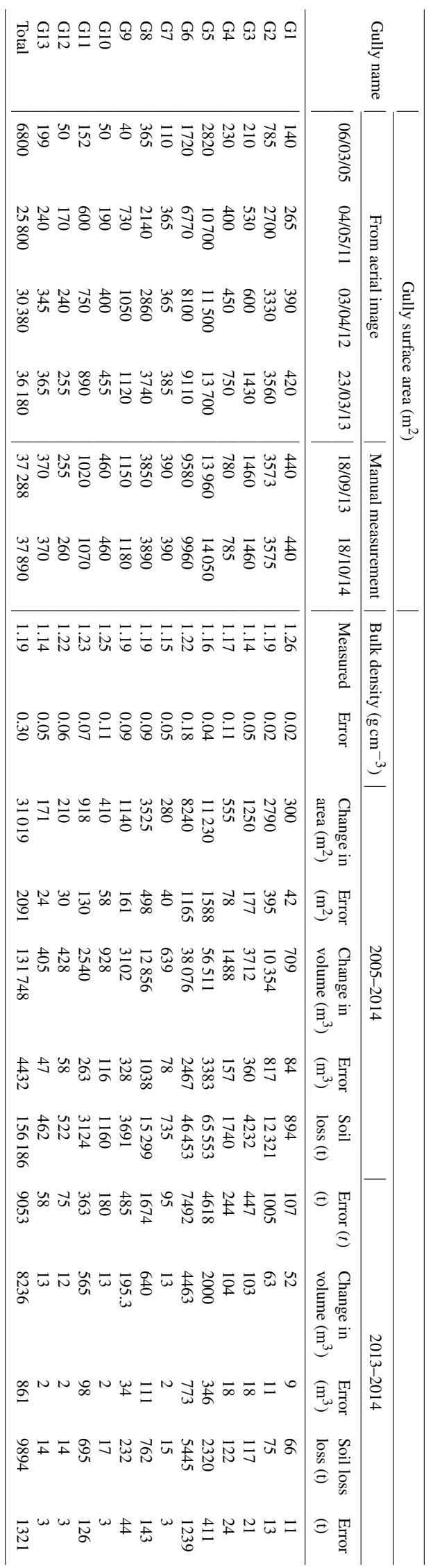

was derived from the digitized gully surface area through a regression of the surface area and volume of the measurements of the 13 gullies with surface area in 2013 ranging from 260 to $14050 \mathrm{~m}^{2}$ (Table 2, Fig. S1a). The following regression equation was obtained.

$V=0.54 S^{1.226} \quad R^{2}=0.98$

where $S$ is the gully surface area $\left(\mathrm{m}^{2}\right)$ obtained from Google Earth and $V$ is the predicted volume $\left(\mathrm{m}^{3}\right)$ of the gully. The total gully volume for the entire watershed is then simply the sum of all individual gully volumes. The goodness-of-fit parameters (see Sect. 2.2.4) between measured volume and estimated (Eq. 4) volume (Fig. S1b in the Supplement) are $R^{2}=0.98, \mathrm{NSE}=0.99$, and PBIAS $=-0.8 \%$. Obviously Eq. (4) is only valid in the subhumid Debre Mawi watershed, where the valley soils are deep and the depth is not restricted by bedrock. The area-tovolume relationship developed by Frankl et al. (2013b) for gullies in the semiarid Ethiopian Highlands has a different form because of bedrock at shallow depth that limits the vertical growth.

\subsubsection{Additional measurements to determine factors controlling gully expansion}

Ground water elevation is believed to be one of the most important factors for gully formation and bank instability (Tebebu et al., 2010). Therefore, groundwater depths were measured using a piezometer installed $5-10 \mathrm{~m}$ above each gully head (13 piezometers). Intrusion of silt and sand to the piezometer was prevented by wrapping filter fabric around the $40 \mathrm{~cm}$ long screened bottom end. All piezometers were capped to prevent rainwater entry and were set in concrete to prevent any physical damage. Groundwater table elevations were read using a measuring tape twice a day: in the morning and in the evening.

Daily precipitation was measured at 5 min intervals using an automatic, self-emptying, tipping-bucket rain gauge installed in the northern portion of the watershed. The drainage area (DA) above the gully heads was determined from topographic analysis in a geographical information system (GIS) using a digital elevation model (DEM) with $30 \mathrm{~m}$ horizontal resolution.

A total of 55 soil samples for bulk density (BD) and for textural analysis were collected from different soil layers along the profile of the sidewalls near the gully head (the number of layers varied from three to five depending on the gully depth). Samples for BD were collected with a $98 \mathrm{~cm}^{3}$ ( $5 \mathrm{~cm}$ high) cylindrical core sampler. Soil samples were dried for $24 \mathrm{~h}$ at $105^{\circ} \mathrm{C}$, and bulk density was calculated by dividing the mass of the oven-dried soil by the volume of the core. The textural analysis was carried out using the hydrometer method after sieving (Day, 1965). 


\subsubsection{Statistical and uncertainty analysis}

The statistical measures used to evaluate the goodness of fit of the empirical relationships were the coefficient of determination (Eq. 5), the Nash-Sutcliffe efficiency (Eq. 6) and percent bias (Eq. 7):

$$
\begin{gathered}
R^{2}=\frac{\sum_{i}\left(x_{i}-\bar{x}\right)\left(y_{i}-\bar{y}\right)}{\sqrt{\sum_{i}\left(x_{i}-\bar{x}\right)^{2}\left(y_{i}-\bar{y}\right)^{2}}}, \\
\mathrm{NSE}=1-\frac{\sum_{i}\left(y_{i}-x_{i}\right)^{2}}{\sqrt{\sum_{i}\left(y_{i}-\bar{y}\right)^{2}}}, \\
\mathrm{PBIAS}=\frac{\sum_{i}\left(x_{i}-y_{i}\right)}{\sqrt{\sum_{i} y_{i}}} \cdot 100,
\end{gathered}
$$

where $x_{i}$ and $y_{i}$ are the predicted and the observed values, respectively, and the overbar indicates their arithmetic mean value. The $R^{2}$ (ranging from 0 to 1 ) describes the degree of collinearity between predicted and measured data and is sensitive to extreme values and insensitive to proportional differences. NSE is a normalized statistic that determines the relative magnitude of the residual variance (ranging from $-\infty$ to 1). In general, based on Ritter and Muñoz-Carpena (2013), NSE $>0.65$ is considered acceptable, NSE $=1$ indicates a perfect fit, and an NSE $<0$ suggests that the mean of the observed values is a better predictor than the evaluated model itself. PBIAS is the average tendency of predicted values with respect to their observed counterparts (ranging between -100 and +100$)$. The optimal value of PBIAS is zero, with values close to zero indicating accurate model simulation.

In order to determine the uncertainty of the calculated gully expansion metrics, the following errors were considered: (1) error generated from using the average bulk density to calculate the mass of soil loss, (2) measurement errors of length, width, and cross-sectional area of the gully, and (3) the accuracy of the drainage area estimated from the DEM.

We obtained the measurements errors as follows. The bulk density measurement error was equated with the standard deviation of all bulk density samples (three to five samples were taken for up to five layers of each gully). The absolute measurement error of the gully length and width was assumed to be related to tape measurement and was estimated at $0.1 \mathrm{~m}$. The absolute measurement error of the cross-sectional area was $1 \mathrm{~m}^{2}$ based on previous experience.

The absolute drainage area (DA) measurement error was mainly attributed to the accuracy of the DEM that was used to delineate the drainage area. For this, we used the relationship of the relative errors (\% $\mathrm{re}_{\mathrm{DA}}$ ) in 14 subcatchments studied by Oksanen and Sarjakoski (2005), which is
$\%$ re $_{\mathrm{DA}}=11.3 \exp (-0.0006 \mathrm{DA})$. The absolute error is then $e_{\mathrm{DA}}=0.113 \mathrm{DA} \exp (-0.0006 \mathrm{DA})$.

To calculate the uncertainty of the surface area $(S)$, volume $(V)$ and soil loss (SL) of the gullies we used the method presented by $\mathrm{Ku}(1966)$ on the propagation error $(e)$ as

$e(x \pm y)=\left[(e(x))^{2}+(e(y))^{2}\right]^{1 / 2}$,
$e(x y)=|x y| \cdot\left[(e(x) / x)^{2}+(e(y) / y)^{2}\right]^{1 / 2}$,

where $e(x)$ and $e(y)$ are the absolute errors of the variables $x$ and $y$ that stand for either length, width, area, volume, or bulk density. The absolute error for headcut retreat measurement in each gully was obtained by first calculating the absolute error for each gully segment using Eqs. (8) and (9). Finally, we used Eq. (8) to calculate the combined error from all segments in each gully (Table 3 ). The absolute relative error in predicting gully volume for the 13 gullies was obtained by subtracting the measured volume from the predicted gully volume using Eq. (4) and then dividing for each gully by the measured value. Then we calculated the combined error for the combined volumes of the 13 gullies using Eq. (8). The error in volume $\left(e_{\mathrm{v}}\right)$ calculated from the digitized surface area for all gullies in the watershed was estimated based on the errors calculated from the 13 gullies investigated in more detail. This relationship is as follows: $e_{\mathrm{v}}=0.25 \mathrm{~S}^{1.02}$

\section{Results}

\subsection{Gully expansion rates at the watershed scale (2005-2013)}

The expansion of the gully network in the Debre Mawi watershed significantly impacted the landscape (Table 1, Fig. S2 in the Supplement). Based on the digitized aerial images of 2005 and 2013 we found that the total length of the gully network increased from $8.7 \mathrm{~km}$ in 2005 to $26 \mathrm{~km}$ in 2013 (Table 1, Table S1 in the Supplement). The surface area taken up by the gully expanded from $4.5 \pm 0.17$ ha in 2005 to $20.4 \pm 0.4$ ha (or $3 \%$ of the watershed) in 2013 , or equiv-

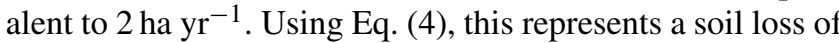
about $0.80 \pm 0.013 \mathrm{Mt}$, which is equivalent to $127 \mathrm{tha}^{-1} \mathrm{yr}^{-1}$ (Tables 1 and 2).

\subsection{Expansion rates of the 13 gullies (2005-2014)}

In this section we discuss the 13 gullies (G1-G13) monitored in more detail. They have a combined watershed area of $200 \pm 9.4$ ha (Table 3). Measurements were used from both aerial imagery (up to 23 March 2013) and manual measurement (2013-2014 rain phases) (Table 2). The surface area of the 13 gullies was $0.7 \pm 0.05$ ha in 2005 and expanded to a total of $3.8 \pm 0.26$ ha in 2014 . The corresponding soil loss from these gullies between 2005 and 2014 was estimated at $156 \pm 9 \mathrm{t}$ (Table 2). This is equivalent to $78 \mathrm{tha}^{-1} \mathrm{yr}^{-1}$ (ranging from 7 to $350 \mathrm{t} \mathrm{ha}^{-1} \mathrm{yr}^{-1}$ with 

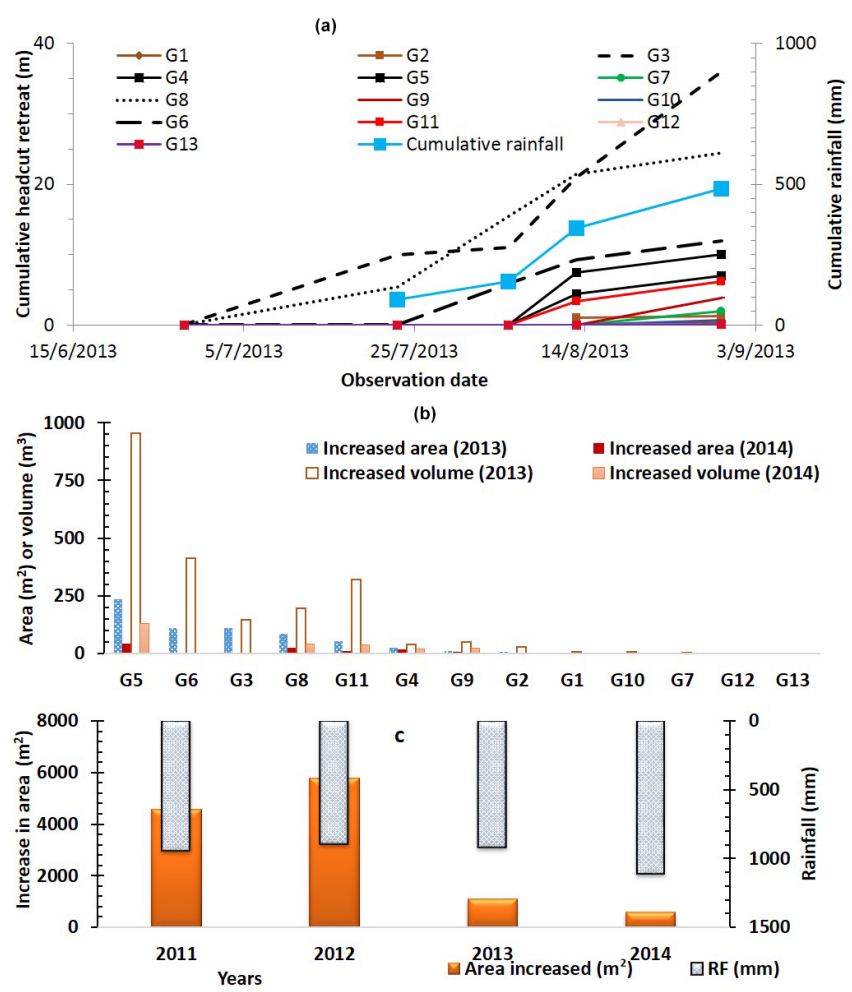

Figure 4. The observed expansion of the 13 study gullies in the Debre Mawi watershed (see Fig. 2 for gully location): (a) cumulative headcut retreat and rainfall during the 2013 rain phase, (b) increase in gully surface area and volume during the 2013 and 2014 rain phases, and (c) increase in the combined gully surface area and the total summer rainfall (RF) between 2011 and 2014.

standard deviation of $90 \mathrm{tha}^{-1} \mathrm{yr}^{-1}$ for the individual gullies). During the last 2 years of the study (2013-2014), the land area lost due to the expansion of the 13 gullies was $0.17 \pm 0.014$ ha (Table 2), which is about $10000 \mathrm{t}$ of soil (of which about $60 \%$ or $47 \mathrm{tha}^{-1}$ occurred in 2013) and is equivalent to $25 \pm 0.8 \mathrm{tha}^{-1} \mathrm{yr}^{-1}$. The soil loss of the individual gullies ranged from $14 \pm 3 \mathrm{t}\left(1.5 \pm 0.3 \mathrm{tha}^{-1} \mathrm{yr}^{-1}\right)$ for $\mathrm{G} 12$ to $5445 \pm 804 \mathrm{t}\left(205 \pm 52 \mathrm{tha}^{-1} \mathrm{yr}^{-1}\right)$ for G6 (Table 2). In 2014, the longitudinal growth of most gullies (G1, G2, G3, G6, G7, G10, G12, and G13) was significantly reduced resulting in less annual soil loss (Table 3 ).

The recorded precipitation during the 2013 rain phase (44 days of rainfall) was $917 \mathrm{~mm}$, and in 2014 (31 days of rainfall) it was $1107 \mathrm{~mm}$ (Fig. 4c). The gully headcut retreat in 2013 ranged from 0.04 to $36 \mathrm{~m}$, with a combined total of $103 \mathrm{~m}$ (Fig. 4a, Table 3), whereas the total retreat in 2014 ranged from 0 to $7 \mathrm{~m}$, with a combined total of $19 \mathrm{~m}$ (Table 3). Over these two monsoon seasons (2013-2014), about $608 \pm 33 \mathrm{~m}^{2}$ of cultivated land was consumed by only the longitudinal headcut retreat of the 13 gullies. This is equivalent to $36 \%$ of the increase in total surface area (both longitudinal and lateral retreat of the entire gully) of the 13 gullies during 2013-2014, and about $1.5 \%$ of the total sur-

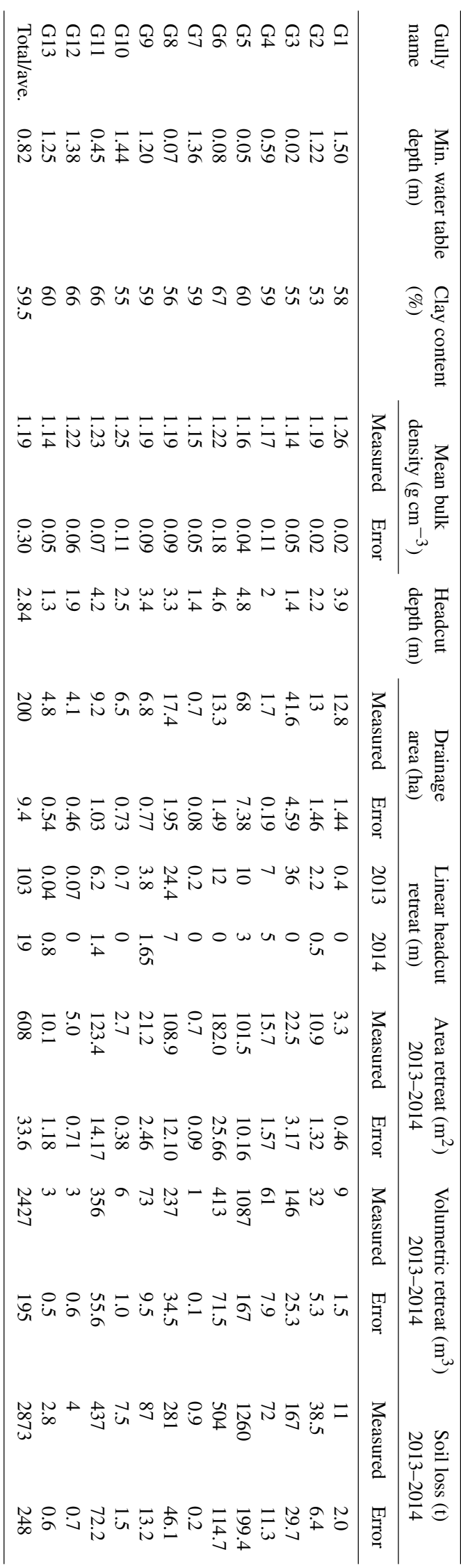


face area of the 13 gullies since their formation up to 2014 . During 2013-2014, the soil loss solely due to headcut migration equalled $2875 \pm 248 \mathrm{t}$ (Table 3), which represented $30 \%$ of the total soil loss from the 13 gullies in the same period presented in Table 2. The total 2-year soil loss caused by the linear headcut retreat of the individual gullies varied from 0.9 (G7) to $1260 \mathrm{t}$ (G5) (Fig. 4b, Table 3). During 2013, only 6 of the 13 gullies (G3, G4, G5, G6, G8, and G11) actively expanded, with lateral retreat (widening) varying from 3 to $11 \mathrm{~m}$ and a headward retreat varying from 6 to $36 \mathrm{~m}$, while the other gullies remained fairly stable. The headcuts of gullies G3 and G8 migrated the farthest, 36 and $24 \mathrm{~m}$, respectively, but only during the 2013 rain phase. However, because of the relatively shallow headcut depth $(1.4 \mathrm{~m})$ and narrow width $(2.6 \mathrm{~m})$ of gully $\mathrm{G} 3$, its headcut migration contributed little (only $7 \%$ ) to the total soil loss of the 13 gullies (Fig. 4b). As shown in Fig. 4b, the four largest gullies (G5, G6, G8, and G11) were responsible for about $94 \%$ of the total soil loss from the 13 gullies. The relationships between the lateral and longitudinal retreat and the associated volumetric soil losses are discussed in Sect. 4.

\subsection{Factors controlling gully headcut retreat and their relationships with gully dimensions (2013)}

The linear headcut retreat of the gullies varied by more than an order of magnitude and was not related to geographic location. This variation should, therefore, be explained by other factors, including groundwater elevation, soil physical properties (texture, bulk density, and porosity), gully head height, and drainage area (Table 3).

The correlation between the observed change in linear gully headcut retreat $\left(R_{\mathrm{L}}\right)$ and the precipitation recorded during the day of the gully head retreat occurrence varied between -0.23 and 0.88 . Some of the big gullies such as G5, G6, and G11 showed strong correlation $\left(R_{\mathrm{L}, \mathrm{G} 5}=0.88\right.$, $p=0.009$ and $\left.R_{\mathrm{L}, \mathrm{G} 6}=0.84, p=0.017\right)$, whereas gullies with the greatest linear retreat $\left(L_{\mathrm{G} 3}=36 \mathrm{~m}\right.$ and $L_{\mathrm{G} 8}=24 \mathrm{~m}$; Fig. 4a) showed weak relationships $\left(R_{\mathrm{L}, \mathrm{G} 3}=0.27, p=0.55\right.$ and $R_{\mathrm{L}, \mathrm{G} 8}=0.34, p=0.37$ ). The fairly low correlation coefficient is likely caused by the time delay between daily rainfall and saturation of the soil surrounding the gully (Tebebu et al., 2010; Tilahun et al., 2013b). Saturation of the gully banks is principally responsible for destabilizing the gully head (Tebebu et al., 2010). Due to such slow saturation processes, the daily precipitation and gully head retreat on the same day are not correlated well. This does not mean that precipitation was not related to retreat since the largest retreat rates were observed on 13 August 2013, after the maximum recorded daily rainfall (94 mm) on 7 August 2013, with little or no rainfall within this period (Fig. 4a).

The combined linear retreat (daily and cumulative) of the 13 gully heads in 2013 was compared with three different rainfall amounts: daily rainfall recorded during the retreat events, cumulative rainfall between gully head retreat events, and the cumulative rainfall since the beginning of the rain phase. The combined linear headcut retreat showed a moderate relationship with daily rainfall $\left(R_{\mathrm{L}}=0.76, p=0.13\right)$ but fairly strong relationship with cumulative rainfall between retreat events $\left(R_{\mathrm{L}}=0.91, p=0.01\right)$. Note that the relationship with daily rainfall was relatively high due to the retreat that occurred on 13 August 2013 during the largest rainfall event as discussed above. When this rainfall was excluded from the analysis, the correlation was reduced to $R_{\mathrm{L}}=0.035(p=0.95)$. The combined cumulative linear retreat was highly correlated with the cumulative rainfall since the beginning of the rain phase $\left(R_{\mathrm{L}}=0.99, p=0.0001\right)$. This clearly indicates that cumulative rainfall, and thus gradual wetting and saturation of the soil, is more important to headcut retreat than the wetting and surface runoff from daily rainfall or individual storms.

The drainage area for the studied gullies varied from 0.7 $( \pm 0.1)$ to $68( \pm 7)$ ha with an average value of 15.4 ha and standard deviation of 18.9 ha (Table 3 ). In order to understand whether drainage area is related to both linear and volumetric retreat of the gully in 2013, simple linear regression models (Eqs. 10 and 11) and power-law relationships (Eqs. 12 and 13) between drainage area (DA, in ha) and cumulative headcut retreat length $(L$, in $\mathrm{m})$ and increase in gully volume ( $V$ in $\mathrm{m}^{3}$ ) were developed. Since rainfall in 2014 was less erosive and small gullies did not retreat, we did not use regression relationships for the 2014 rain phase.

$$
\begin{aligned}
& L=0.3 \mathrm{DA}+3.15,\left(R^{2}=0.28, p=0.06\right) \\
& V=11.7 \mathrm{DA}-13.2,\left(R^{2}=0.67, p=0.0007\right)
\end{aligned}
$$

Fitting a power-law relationship between both the linear $(L)$ and volumetric $(V)$ gully retreat and drainage area yielded

$$
\begin{aligned}
& L=0.21(\mathrm{DA})^{1.047},\left(R^{2}=0.33\right), \\
& V=2.32(\mathrm{DA})^{1.26},\left(R^{2}=0.48\right) .
\end{aligned}
$$

The predicted $L$ and $V$ using Eqs. (10) and (11) were compared linearly with the measured $L$ and $V$. The goodness-of-fit parameters for the length $L$ and volume $V$ were $R_{\mathrm{L}}^{2}=0.28 \quad(p=0.06), \quad \mathrm{NSE}_{\mathrm{L}}=0.11$, and PBIAS $_{\mathrm{L}}=52 \%$ and $R_{\mathrm{V}}^{2}=0.69(p \ll 0.01), \mathrm{NSE}_{\mathrm{V}}=0.47$, and PBIAS $_{\mathrm{V}}=49 \%$, respectively. Similarly, the predicted $L$ and $V$ using power-type regression equations (Eqs. 12 and 13) were compared with the measured $L$ and $V$. The goodness-of-fit parameters were $R_{\mathrm{L}}^{2}=0.33, \mathrm{NSE}_{\mathrm{L}}=-0.36$, and PBIAS $_{\mathrm{L}}=98 \%$ and $R_{\mathrm{V}}^{2}=0.48, \quad \mathrm{NSE}_{\mathrm{V}}=0.48$, and PBIAS $_{\mathrm{V}}=49 \%$. For both the linear and power-type fitting, the $R^{2}$ and NSE of the volumetric gully retreat were larger than those for the gully linear retreat.

Figure 5 shows the water table rose above the gully bottom for all 13 gullies during the rain phase, which indicates mostly saturated gully head and bank soils. In this study, the water table measurements were carried out twice a day (i.e., in the morning and evening). The groundwater table fluctuated between these readings (Fig. 5), but the variation was 
Table 4. Power-type and linear regression equations of the longitudinal headcut retreat, $L$, and the volumetric gully expansion, $V$, with the controlling factors, $X$, listed in the first column: $L$ or $V=a X^{b}$. The goodness of the fit is represented by the coefficient of determination, $R^{2}$.

\begin{tabular}{|c|c|c|c|c|c|c|c|c|c|c|}
\hline \multirow[t]{2}{*}{ Controlling factors $(X)$} & \multicolumn{3}{|c|}{$L=a X^{b}$} & \multicolumn{2}{|c|}{$\begin{array}{l}\text { For linear regression } \\
\text { equation of } L \text { with }(X)\end{array}$} & \multicolumn{3}{|c|}{$V=a X^{b}$} & \multicolumn{2}{|c|}{$\begin{array}{l}\text { For linear regression } \\
\text { equation of } V \text { with }(X)\end{array}$} \\
\hline & $a$ & $b$ & $R^{2}$ & $R^{2}$ & $p$ value & $a$ & $b$ & $R^{2}$ & $R^{2}$ & $p$ value \\
\hline Water table & 0.73 & 1.11 & 0.62 & 0.64 & 0.001 & 12.7 & 1.09 & 0.60 & 0.49 & 0.009 \\
\hline Drainage area & 0.21 & 1.047 & 0.33 & 0.28 & 0.06 & 2.32 & 1.26 & 0.47 & 0.67 & 0.0007 \\
\hline Headcut depth & 0.25 & 2.16 & 0.21 & 0.0004 & 0.9 & 1.57 & 3.24 & 0.47 & 0.49 & 0.007 \\
\hline Clay content & 110.7 & -1.05 & 0.023 & 0.05 & 0.46 & 0.000 & 4.04 & 0.018 & 0.08 & 0.35 \\
\hline Bulk density & 5.73 & -6.2 & 0.008 & 0.13 & 0.23 & 26.8 & 1.28 & 0.0004 & 0.02 & 0.67 \\
\hline
\end{tabular}

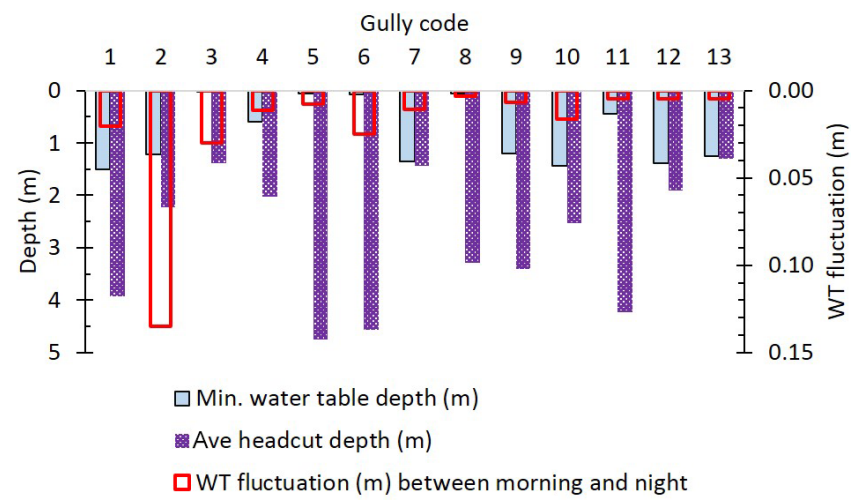

Figure 5. Comparison of minimum groundwater table depth, gully headcut depth, and the average groundwater table (WT) fluctuation between morning and night for the 13 study gullies in the Debre Mawi watershed, Ethiopia, for the 2013 rain phase.

not significant $(p=0.98)$. The water table decreased between morning and evening readings on average by $0.7 \mathrm{~cm}$ with a standard deviation of $4.0 \mathrm{~cm}$. The greatest fluctuations were observed at G2 (Fig. 5). The power-type regression model between the minimum water table depth during the rain phase (ranging from $0.02 \mathrm{~m}$ at G3 to $1.5 \mathrm{~m}$ at G1) and the linear retreat and volumetric expansion of the 13 gullies had fairly high coefficients of determination with length $\left(R_{\mathrm{L}}^{2}=0.62\right)$ and volume $\left(R_{\mathrm{V}}^{2}=0.60\right)$ (Table 4$)$.

By fitting a simple linear regression, the volumetric gully expansion was significantly related to the height of the gully headcut $\left(R_{\mathrm{V}}^{2}=0.49, p=0.007\right)$. However, the linear retreat of the gully was not explained by the headcut height $\left(R_{\mathrm{L}}^{2}=0.0004, p=0.9\right)$. The reason is likely the fact that gully G3, which had large linear retreat but small headcut height, affected the analysis. When this gully is excluded from the analysis, the $R_{\mathrm{L}}^{2}$ for the linear and power relationship between the gully linear retreat and gully head height increased from 0.0004 to $0.26(p=0.09)$ and from 0.21 to 0.52 , respectively. In this case, the gully height fairly well explained the linear retreat. Note that gully heads of lower height are relatively more stable than those with greater heights as the factor of safety for stability is approximately inversely proportional to gully head height. An equivalent increase in gully head stability can be obtained by regrading the gully head to a lower slope.

The major soil texture for all gully banks was clay-sized (53 to $67 \%$ with standard deviation of $4.5 \%$ ), and an average bulk density of $1.2 \pm 0.3 \mathrm{~g} \mathrm{~cm}^{-3}$ (Table 3 ). The gully head retreat rates were only weakly correlated with the texture (Table 4), probably because of the limited variation in soil texture. Linear regression and power-type regression of clay content with the volumetric and linear headcut retreat were therefore not significant (Table 4).

\section{Discussion}

\subsection{Effects of gully erosion on agricultural lands}

Gully expansion affects the economic feasibility of soil conservation measures in reducing the amount of land available to farm. In 2013, the net gully area in the Debre Mawi watershed was $3 \%$ of the watershed area. If additional strips of $1 \mathrm{~m}$ width on each side of the gully area is not cultivated, the total area taken up by gullies becomes $5 \%$ of the total watershed area.

Most gullies in the watershed were not stable and impaired more than 16 ha of agricultural land from 2005 to 2013 . Gully expansion in the Debre Mawi watershed is not evenly distributed because the upper slopes of the watershed (about $50 \%$ of the watershed area) reduces gully formation mainly because it does not saturate (Tilahun et al., 2013b; Steenhuis et al., 2014; Tebebu et al., 2015). Gully expansion therefore affects mostly the bottomlands, where soils become saturated around the beginning of July (Tilahun et al., 2013b). A loss of 2 ha of productive farmland per year is considerable for any farmer, but even more significant in a region with smallholder farmers. As farmers' land holding in the Ethiopian Highlands is about 1 ha of land per household (Sonneveld and Keyzer, 2003), the land loss observed between 2005 and 2013 could have provided farmland for 16 farming households in the watershed. 
The rate of soil erosion (2005-2014) due to gully expansion in the subhumid Debre Mawi watershed $\left(127 \mathrm{tha}^{-1} \mathrm{yr}^{-1}\right)$ is more than 5 times as much as the upland erosion reported by Tebebu et al. (2010) and Zegeye et al. (2010) in this watershed. The soil loss relative to the change in gully surface area is about $4000 \mathrm{tha}^{-1} \mathrm{yr}^{-1}$ or $400 \mathrm{~kg} \mathrm{~m}^{-2} \mathrm{yr}^{-1}$, which is more than 2-fold the rate reported by Daba et al. (2003) for semiarid eastern Ethiopia over a 30-year period. One of the reasons for the difference is that the gullies in the subhumid Debre Mawi watershed are much deeper than in the semiarid area studied by Daba et al. (2003). Another reason is that the soils are more often saturated in a humid climate than in semiarid areas. Upland soil and water conservation practices are not effective for areas with gullies because sediment concentration in the runoff increased greatly, effectively negating any positive effect of upstream practices (Zegeye et al., 2015).

\subsection{The relationship between gully headcut dimensions and their controlling factors}

Table 5 lists the goodness-of-fit parameters Eqs. (5-7) of the power-law and linear regression relations between the change in gully volumetric headcut erosion $(V)$, the top width retreat or lateral expansion $(W)$, and the linear headward migration of the headcut $(L)$. Both the power and linear regression analyses (Table 5) show that the volumetric gully expansion $(V)$ was strongly related to top width retreat $(p<0.01)$, whereas no significant relation was found between $V$ and $L(p=0.36)$. Similar results were obtained using a power-law relationship (Table 5). Additionally, as shown in Table 1, the relative change between 2005 and 2013 in net gully area (350\%) is more than 2-fold the relative change in length (199\%). This indicates that sideways or lateral gully retreat is a more important mechanism of soil loss and gully expansion than linear migration of gully headcuts. Note that the $R^{2}$ value can sometimes be misleading, as indicated by the other goodness-of-fit parameters assessed. For example, the $V-L$ power-law relationship for all 13 gullies has an $R^{2}=0.83$, which indicates a good fit between gully volume and linear gully extension. However, based on NSE and PBIAS (Table 5), the relationship between gully volumetric expansion predicted by the $V-L$ equation $\left(V=18.3 \mathrm{~L}^{0.91}\right)$ and the observed volumetric expansion is not in the acceptable range (NSE $=-0.004$, PBIAS $=-32.4)$. This indicates that assessing the quality of fits between gully expansion parameters cannot solely be done based on $R^{2}$, and that good fits also require other measures like NSE and PBIAS to be in the acceptable range.

Both the linear (Eqs. 10 and 11) and power-type (Eqs. 12 and 13) regression relationships indicated that drainage area predicted the volumetric gully erosion $(V)$ better than the linear headward migration $(L)$ of the gully headcut. This suggests that the larger the drainage area, the greater the lateral expansion is by collapsing gully banks, and hence the greater the sediment production. Studies in the semiarid Ethiopian Highlands with relatively shallow soils over bedrock have indicated that drainage area (which was not significantly related in the Debre Mawi catchment with deep soils) was a major controlling factor of gully head retreat (Poesen et al., 2003; Frankl et al., 2012).

Similar relationships were also developed by Vandekerckhove et al. (2003) for semiarid southeastern Spain $\left(V=0.069 \mathrm{DA}^{0.38}, R^{2}=0.51\right)$ and Frankl et al. (2012) for the semiarid Tigray region in northern Ethiopia $\left(V=0.53 \mathrm{DA}^{0.31}, R^{2}=0.27\right)$. Note that, in the Debre Mawi watershed, gully volume expansion is stronger related to drainage area than in southeastern Spain and the Tigray region, as the power-law exponent is about 4 times greater in the Debre Mawi watershed: the larger the exponent, the greater the increase in $V$ per unit increase in drainage area (Frankl et al., 2013b). The ratio of the volumetric expansion relations for Debre Mawi and the Tigray region is $4.4 \mathrm{DA}^{0.95}$, which shows a near linear increase in this ratio with drainage area. For a gully draining 10 ha of land in the Debre Mawi watershed, the volumetric expansion is on average almost 40 times greater than that of a gully draining the same area in the semiarid Tigray region studied by Frankl et al. (2012). The greater retreat rates in Debre Mawi are caused by the rainfall amounts during the rain phase exceeding potential evaporation with excess water saturating the valley bottoms (see Sect. 3.3). In addition, the Vertisol soils are up to $10 \mathrm{~m}$ deep overlying the bedrock. This combined with high groundwater tables indicates the potential for erosion is greater in the Debre Mawi watershed compared with the drier semiarid regions of Tigray and southeastern Spain, where soils are also thinner. These findings are in accordance with Frankl et al. (2013b) in that the establishment of relationships like Eqs. (12) and (13) is necessarily region-specific and only representative of similar environmental settings with respect to climate, topography, lithology, soil, and vegetation.

\subsection{Viable gully erosion control measures for the subhumid Ethiopian Highlands}

Gully erosion can rapidly change landscapes as can be seen for instance for G6, G8, and G11 in Fig. 6. Gully G6 has expanded laterally into cultivated land through erosion of the right bank (west bank), whereas lateral erosion of the left bank, located on grassland, was rather limited. This decreased gully expansion on the grassed bank may be due to the effect of the grasses either in terms of increasing the topsoil shear strength (De Baets et al., 2008) or drying out the soil through evapotranspiration (Pollen and Simon, 2005) and thereby reducing soil saturation. Also, grasses could modify overland flow and infiltration patterns and therefore affect subsurface drainage. Gully G11 was surrounded by cultivated land on both sides and hence expanded laterally through erosion of both left (south) and right (north) banks. In 2012 the land adjacent to the left bank was planted with 
Table 5. Relationships of the volumetric gully headcut erosion $(V)$ with the headward migration length $(L)$ and the lateral erosion $(W)$ during the 2013 rain phase for the 13 gullies in the Debre Mawi watershed. The observed gully volumes were fitted as functions of $L$ or $W$ using power-law and linear regression models. $V-W$ and $V-L$ refer to $V$ as a function of $W$ or $L$, respectively.

\begin{tabular}{|c|c|c|c|c|c|c|c|}
\hline \multirow{2}{*}{ Relationship } & \multicolumn{4}{|c|}{ Power-law relationship $\left(V=a x^{b}\right)$} & \multicolumn{3}{|c|}{ Predicted versus measured } \\
\hline & $a$ & $b$ & $R^{2}$ & & $R^{2}$ & NSE & PBIAS \\
\hline$V-W$ & 0.65 & 2.15 & 0.63 & & 0.63 & 0.89 & -21 \\
\hline \multirow[t]{3}{*}{$V-L$} & 18.3 & 0.91 & 0.83 & & 0.83 & -0.004 & -32.4 \\
\hline & \multicolumn{4}{|c|}{ Linear regression $(V=m x+n)$} & \multicolumn{3}{|c|}{ Predicted versus measured } \\
\hline & $m$ & $n$ & $R^{2}$ & $p$ & $R^{2}$ & NSE & PBIAS \\
\hline$V-W$ & 33 & -115 & 0.87 & $6.2 \times 10^{-6}$ & 0.89 & 0.88 & 11 \\
\hline$V-L$ & 6.9 & 112 & 0.07 & 0.36 & 0.08 & 0.08 & 0 \\
\hline
\end{tabular}

$x$ represents $W$ or $L ; a, b, m$, and $n$ are constants.
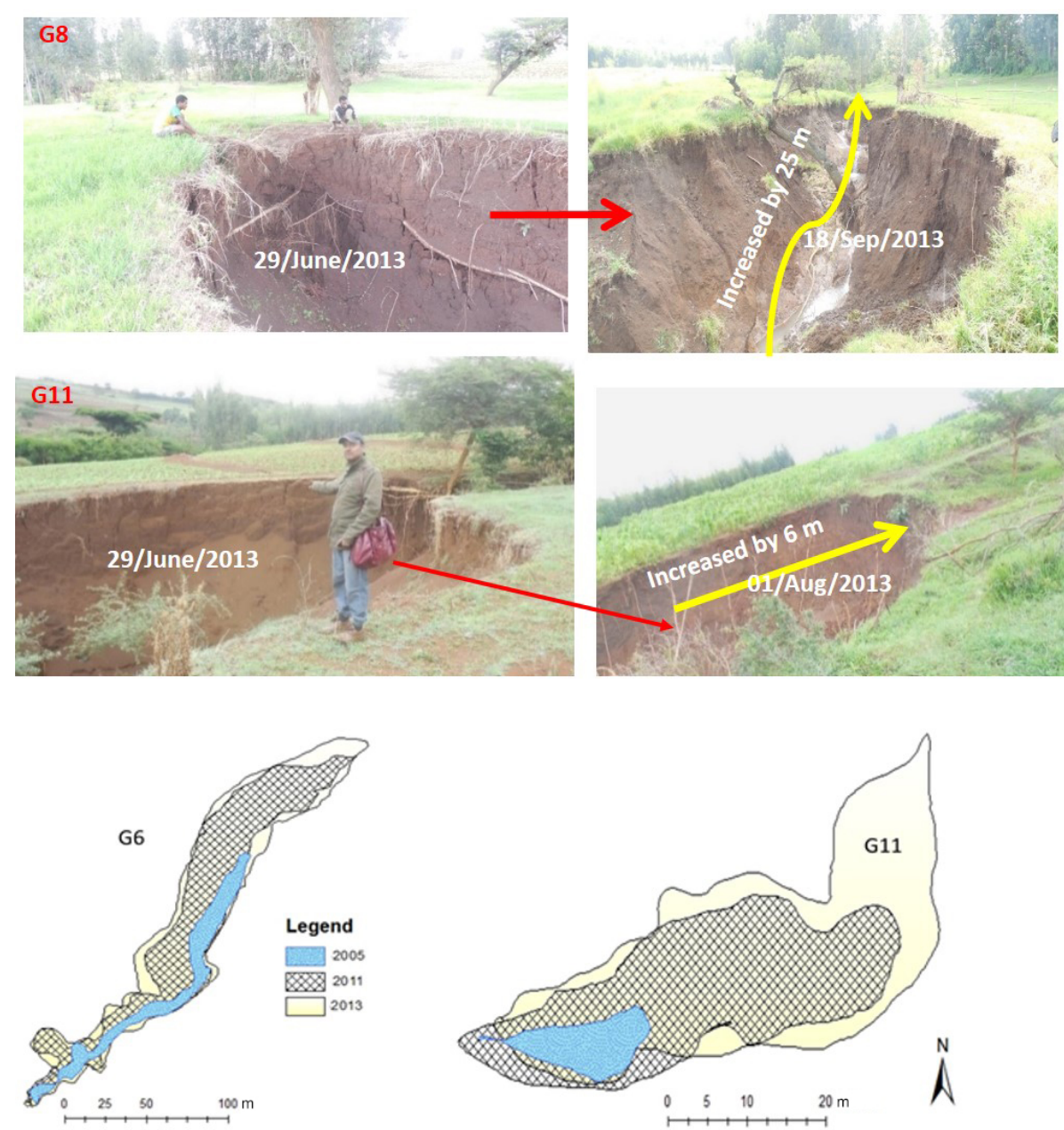

Figure 6. Examples of gully expansion in the Debre Mawi watershed. Top four photos: expansion of gullies G8 and G11 during the 2013 rain phase and the trees which fell into the gullies from upstream. Bottom images: expansion of gullies G6 and G11 between 2005 and 2013.

eucalyptus trees to halt erosion. In 2013, erosion of this left (south) bank was significantly reduced, and gully development then occurred through extension in northeastern direction and lateral expansion in northern direction instead (see
Fig. 6). The lesson learned from these two gullies (G6 and G11) is that vegetation may reduce gully expansion by increasing soil shear strength through their roots, slowing down the storm runoff, and trapping sediments, which was also ob- 
served by, among others, Gyssels and Poesen (2003) and De Baets et al. (2006). Therefore, planting suitable species on the gully face and around the boundary may reduce or slow down bank failure and water-induced erosion, especially for fairly deep gullies. In contrast to the above explanation, although both banks of G8 were surrounded by grasses (Fig. 6), the gully head migrated uphill by about $25 \mathrm{~m}$ in 2 months. The reasons for this could be that (1) both banks were steep and deep enough for gravity-induced bank failure and that (2) the surrounding soil was highly saturated (Table 3) and bank layers near the bottom were more erodible than the overlying layer, causing a preferential retreat that undercut the bank and consequent cantilever failures (Fig. S3 in the Supplement).

Our monitoring data also contained valuable information regarding the effectiveness of soil and water conservation measures such as soil bunds that were extensively installed across the upper portion of the catchment since 2012. Dagnew et al. (2015), in the same watershed, reported that soil bunds reduced runoff by $60 \%$, sediment concentration by $36 \%$, and sediment load by $80 \%$, which resulted in a significant reduction of runoff volume and sediment loads in the first 2 years of implementation. However, a reduction of downslope sediment concentration was not significant due to the presence of large gullies near the watershed outlet. Further, the SWC measures (soil bunds), aimed to reduce the development of rills and gullies in the area, were implemented on saturated Vertisol areas and have rather led to gully initiation and development (see Fig. 1f; Steenhuis et al., 2014; Dagnew et al., 2015). These soil and water conservation measures appear to be ineffective on these locations as they cannot reduce or stop upslope gully headcut migration, which requires alternative, structural measures. Similarly, diversion waterways have been tested in the watershed to arrest gully heads but have produced new gully branches (Zegeye et al., 2014). Our data therefore support the findings of Dagnew et al. (2015), which indicate that the extensive implementation of soil and water conservation measures on periodically saturated Vertisol areas may have exacerbated rather than mitigated gully formation and expansion.

In the bottomlands of the watershed with Vertisols dominant, gully formation was severe due to alternate swelling and shrinking of expanding clays resulting in deep cracks in the dry season (Fig. 1c). As was previously observed by Frankl et al. (2012), the shrink-swell behavior of Vertisols eventually developed into pipes (Fig. 1d) and contributed to gully development. Though pipes contribute to gully formation, we observed in this study that they are also important to drain excess subsurface water near the gully banks, thereby potentially mitigating gully expansion. For example, soil pipes in the heads of gullies G7 and G13 drained the elevated groundwater table, resulting in only minor headcut retreat (Table 3). This implies that gully expansion rates could be reduced by controlling the water table and therefore the pore-water pressures in the gully head (Zegeye et al., 2016).
For example, drop pipes are a common practice in the United States (Field Office Technical Guide standard 587; NRCS, 2015 ) to control groundwater and surface water level to halt erosion of gully heads up to $15 \mathrm{~m}$ in height, but they can be very costly (> USD 50000 each). Moreover, most of the Debre Mawi watershed gullies are deep gullies (up to $7 \mathrm{~m}$ ) that are therefore susceptible to gravity-induced bank collapse. Regrading the gully head and bank slopes decreases their weight and reduces the probability of bank failure (Langendoen et al., 2014; Zegeye et al., 2016).

In the semiarid Tigray region of northern Ethiopia, Frankl et al. (2012) recommended the application of a subsurface geo-membrane (vertical dam) at the gully head to increase groundwater levels and subsequently decrease soil cracking and soil piping. However, this may not be effective in the (sub)humid region of the Ethiopian Highlands as we have shown that elevated groundwater tables increases the rate of gully expansion (Table 4, Fig. 1f). Therefore, gully mitigation measures in the subhumid Ethiopian Highlands and similar climate types should aim to reduce soil water content.

\section{Conclusions}

Field observations in the Debre Mawi watershed indicate that permanent valley-bottom gully drainage networks and in particular gully widening and headcut retreat are important erosion processes severely impacting the productive farmlands.

Gully mapping and monitoring indicated that the continued gully incision, lateral expansion, and headward extension are governed by the collapse of the gully head and sidewalls, and the subsequent removal of the failed materials by flowing water (Figs. 1 and 6). About $5 \%$ of the watershed area has been impaired by the expanding gully network. The gully expansion rate at the watershed scale between 2005 and 2013 was $127 \mathrm{tha}^{-1} \mathrm{yr}^{-1}$ (Table 1). The headcut migration of the 13 gullies during the 2013 rain phase varied significantly from 0.04 to $36 \mathrm{~m} \mathrm{yr}^{-1}$ (Table 3 and Fig. 4).

Understanding the controlling factors of gully head migration and lateral expansion of gullies is crucial to design appropriate gully control measures. Retreat rates depended most strongly on groundwater table elevation (Table 4). The elevated water tables saturate the soils surrounding the gullies, thereby reducing the soil erosion resistance. An elevated groundwater table may also lead to seepage-induced erosion. Additionally, the gully head depth and the drainage area, which is representative of surface runoff magnitude, were other factors controlling gully erosion in the Debre Mawi watershed (Table 4). Therefore, conservation practices that address these parameters may be most effective.

The lateral retreat for deep gullies contributes the most to the volumetric gully erosion in the Debre Mawi watershed (Table 5). Therefore, regrading the gully head and bank slopes could reduce the occurrence of gravity-induced bank collapse for deep gullies. Studies need to be designed to eval- 
uate the effects of controlling groundwater movement, for example by subsurface drainage, on the stability of Vertisols. Vegetation may play a vital role in reducing soil water and increasing soil shear strength. The planting of an assemblage of suitable, native plant species (both herbaceous and woody) is being tested in the watershed.

\section{Data availability}

The supplemental data (Excel, movie) for this manuscript are available online from the TIB AV-Portal Data Repository under doi:10.5446/18056.

\section{The Supplement related to this article is available online at doi:10.5194/soil-2-443-2016-supplement.}

Author contributions. Assefa D. Zegeye, Eddy J. Langendoen, Tammo S. Steenhuis, and Seifu A. Tilahun designed the experiments, and Assefa D. Zegeye carried them out. Assefa D. Zegeye, Eddy J. Langendoen, Fasikaw A. Zimale, and Dessalegn C. Dagnew analyzed and interpreted the data. Assefa D. Zegeye, Eddy J. Langendoen, Tammo S. Steenhuis, Cathelijne R. Stoof, Christian D. Guzman, Birru Yitaferu, and Seifu A. Tilahun supervised the research and cooperated on writing (editing, commenting, developing, formatting etc.) the manuscript.

Acknowledgements. This research was supported financially by the Norman E. Borlaug Leadership Enhancement in Agriculture Program (Borlaug LEAP-016258-82), International Foundation for Science (IFS-W/5407-1), Cornell University (Hudson H. Lyon research fund) and the Ithaca Presbyterian Church, and PEER Science Program of USAID (ID-OAA-A-11-00012).

Edited by: Estela N. Romero

Reviewed by: A. Frankl and one anonymous referee

\section{References}

Abiy, A. Z.: Geological controls in the formations and expansions of gullies over hillslope hydrological processes in the highlands of Ethiopia, Northern Blue Nile Region, MPS Thesis, Cornell University, NY, USA, 2009.

Avni, Y.: Gully incision as a key factor in desertification in an arid environment, the Negev Highlands, Israel, Catena, 63, 185-220, 2005.

Begin, Z. B., Meyer, D. F., and Schumm, S. A.: Knick point migration due to base level lowering, Adv. Energy Syst. Div., 106, 369-388, 1980.

Billi, P. and Dramis, F.: Geomorphological investigation on gully erosion in the Rift Valley and the northern highlands of Ethiopia, Catena, 50, 353-368, 2003.
Bayabil, H. K., Tilahun, S. A., Collick, A. S., and Steenhuis, T. S.: Are runoff processes ecologically or topographically driven in the Ethiopian highlands? The case of the Maybar watershed, Ecohydrol., 3, 457-466, 2010.

Campo-Bescós, M. A., Flores-Cervantes, J. H., Bras, R. L., Casalí, J., and Giráldez, J. V.: Evaluation of a gully headcut retreat model using multitemporal aerial photographs and digital elevation models, J. Geophys. Res-Earth, 118, 2159-2173, 2013.

Capra, A., Porto, P., and Scicolone, B.: Relationships between rainfall characteristics and ephemeral gully erosion in a cultivated catchment in Sicily (Italy), Soil Tillage Res., 105, 77-87, 2009.

Casalí, J., Loizu, J., Campo, M. A., De Santisteban, L. M., and Álvarez-Mozos, J.: Accuracy of methods for field assessment of rill and ephemeral gully erosion, Catena, 67, 128-138, 2006.

Casalí, J., Giménez, R., and Campo-Bescós, M. A.: Gully geometry: what are we measuring?, Soil, 1, 509-513, doi:10.5194/soil-1509-2015, 2015.

Daba, S., Rieger, W., and Strauss, P.: Assessment of gully erosion in eastern Ethiopia using photogrammetric techniques, Catena, 50, 273-291, 2003.

Dagnew, D. C., Guzman, C. D., Zegeye, A. D., Tibebu, T. Y., Getaneh, M., Abate, S., Zemale, F. A., Ayana, E. K., Tilahun, S. A., and Steenhuis, T. S.: Impact of conservation practices on runoff and soil loss in the sub-humid Ethiopian Highlands: The Debre Mawi watershed, J. Hydrol. Hydromech., 63, 210-219, doi:10.1515/johh-2015-0021, 2015.

Day, P. R.: Particle fractionation and particle-size analysis, in: Methods of soil analysis, Part 1, edited by: Black, C. A., Evans, D. D., White, J. L., Ensminger, L. E., and Clark, F. E., Agronomy, 9, 545-567, 1965.

De Baets, S., Poesen, J., Gyssels, G., and Knapen, A.: Effects of grass roots on the erodibility of top soils during concentrated flow, Geomorphology, 76, 54-67, 2006.

De Baets, S., Poesen, J., Reubens, B., Wemans, K., De Baerdemaeker, J., and Muys, B.: Root tensile strength and root distribution of typical Mediterranean plant species and their contribution to soil shear strength, Plant Soil, 305, 207-226, 2008.

Engda, T. A., Bayabil, H. K., Legesse, E. S., Ayana, E. K., Tilahun, S. A., Collick, A. S., Easton, Z. M., Rimmer, A., Awulachew, S. B., and Steenhuis, T. S.: Watershed hydrology of the (semi) humid Ethiopian highlands, in: Nile River basin: Hydrology, Climate, and Land Use, edited by: Melesse, A., Springer Science, New York, 145-162, 2011.

Frankl, A., Nyssen, J., De Dapper, M., Haile, Mitiku, Billi, P., Munro, R. N., Deckers, J., and Poesen, J.: Linking long-term gully and river channel dynamics to environmental change using repeat photography (North Ethiopia), Geomorphology, 129, 238-251, 2011.

Frankl, A., Poesen, J., Deckers, J., Haile, M., and Nyssen, J.: Gully head retreat rates in the semi-arid highlands of Northern Ethiopia, Geomorphology, 173, 185-195, 2012.

Frankl, A., Zwertvaegher, A., Poesen, J., and Nyssen, J.: Transferring Google Earth Observations to GIS-software: example from gully erosion study, Int. J. Digital Earth, 6, 196-201, doi:10.1080/17538947.2012.744777, 2013a.

Frankl, A., Poesen, J., Scholiers, N., Jacob, M., Haile, M., Deckers, J., and Nyssen, J.: Factors controlling the morphology and volume $(V)$-length $(L)$ relations of permanent gullies in the North- 
ern Ethiopian Highlands, Earth Surf. Process. Landf., 38, 16721684, 2013b.

Frankl, A., Poesen, J., Haile, M., Deckers, J., and Nyssen, J.: Quantifying long-term changes in gully networks and volumes in dryland environments: The case of Northern Ethiopia, Geomorphology, 201, 254-263, 2013c.

Frankl, A., Deckers, J., Moulaert, L., Van Damme, A., Haile, M., Poesen J., and Nyssen, J.: Integrated solutions for combating gully erosion in areas prone to soil piping: innovations from the drylands of Northern Ethiopia, Land Degrad. Dev., doi:10.1002/ldr.2301, 2014.

Gyssels, G. and Poesen, J.: The importance of plant root characteristics in controlling concentrated flow erosion rates, Earth Surf. Process. Landf., 28, 371-384, 2003.

IUSS Working Group WRB: World Reference Base for Soil Resources 2014, update 2015, International soil classification system for naming soils and creating legends for soil maps, World Soil Resources Reports No. 106, FAO, Rome, 2015.

Jones, J. A. A.: The effects of soil piping on contributing areas and erosion patterns, Earth Surf. Process. Landf., 12, 229-248, doi:10.1002/esp.3290120303, 1987.

$\mathrm{Ku}, \mathrm{H}$. H.: Notes on the Use of Propagation of Error Formulas, JOURNAL OF RESEARCH of the National Bureau of Standards, C. Engineering and Instrumentation, 70C, 263-273, 1966.

Lanckriet, S., Frankl, A., Mesfin, G., Descheemaeker, K., and Nyssen, J.: Gully cut-and-fill cycles as related to agromanagement: a historical curve number simulation in the Tigray Highlands, Earth Surf. Process. Landf., 40, 796-808, doi:10.1002/esp.3687, 2015.

Langendoen, E. J. and Simon, A.: Modeling the evolution of incised streams, II: Streambank erosion, J. Hydraul. Eng., 134, 905-915, 2008.

Langendoen, E. J., Tebebu, T. Y., Steenhuis, T. S., and Tilahun, S. A.: Assessing gully widening and its control in the Debre-Mawi Watershed, northern Ethiopia, in: Proceedings of the first International Conference on Science and Technology towards the Development of East Africa (ICST), Bahir Dar, Ethiopia, 214-222, 2013.

Langendoen, E. J., Zegeye, A. D., Tebebu, T. Y., Steenhuis, T. S., Ayele, G. K., Tilahun, S. A., and Ayana, E. K.: Using computer models to design gully erosion control structures for humid northern Ethiopia, in: Proceedings of Hydro-Engineering for Environmental Challenges, 11th International Conference on Hydroscience \& Engineering (ICHE 2014), Hamburg, 28 September-2 October 2014, 2014.

Muñoz-Robles, C., Reid, N., Frazier, P., Tighe, M., Briggs, S. V., and Wilson, B.: Factors related to gully erosion in woody encroachment in South-Eastern Australia, Catena, 83, 148-157, 2010.

Nyssen, J., Poesen, J., Moeyersons, J., Luyten, E., Veyret, P. M., Deckers, J., Haile, M., and Govers, G.: Impact of road building on gully erosion risk: a case study from the northern Ethiopian Highlands, Earth Surf. Process Landf., 27, 1267-1283, 2002.

Nyssen, J., Veyret-Picot, M., Poesen, J., Moeyersons, J., Haile, M., Deckers, J., and Govers, G.: The effectiveness of loose rock check dams for gully control in Tigray, northern Ethiopia, Soil Use Manage., 20, 55-64, doi:10.1079/SUM2003223, 2004a.

Nyssen, J., Poesen, J., Moeyersons, J., Deckers, J., Haile, M., and Lang, A.: Human impact on the environment in the Ethiopian and Eritrean Highlands: A state of the Art, Earth-Sci. Rev., 64, 273-320, 2004b.

Nyssen, J., Poesen, J., Veyret-Picot, M., Moeyersons, J., Haile, M., Deckers, J., Dewit, J., Naudts, J., Teka, K., and Govers, G.: Assessment of gully erosion rates through interviews and measurements: a case study from northern Ethiopia, Earth Surf. Process. Landf., 31, 167-185, doi:10.1002/esp.1317, 2006.

Nyssen, J., Poesen, J., Moeyersons, J., Haile, M., and Deckers, J.: Dynamics of soil erosion rates and controlling factors in the Northern Ethiopian Highlands-Towards a Sediment Budget, Earth Surf. Process. Landf., 33, 695-711, 2008.

Nyssen, J., Clymans, W., Poesen, J., Vandecasteele, I., De Baets, S., Haregeweyn, N., Naudts, J., Hadera, A., Moeyersons, J., Haile, M., and Deckers, J.: How soil conservation affects the catchment sediment budget - a comprehensive study in the north Ethiopian highlands, Earth Surf. Process. Landf., 34, 1216-1233, 2009.

Oksanen, J. and Sarjakoski, T: Error propagation analysis of DEMbased drainage basin delineation, Int. J. Remote Sens., 26, 30853102, doi:10.1080/01431160500057947, 2005.

Oostwoud Wijdenes, D. G. and Bryan, R. B.: Gully-head erosion processes on a semi-arid valley floor in Kenya: a case study into temporal variation and sediment budgeting, Earth Surf. Process. Landf., 26, 911-933, doi:10.1002/esp.225, 2001.

Poesen, J.: Gully typology and gully control measures in the European loess belt, in: Farm Land Erosion in Temperate Plains Environment and Hills, edited by: Wicherek, S., Elsevier, Amsterdam, 221-239, 1993.

Poesen, J., Nachtergale, J., Vertstraeten, G., and Valentin, C.: Gully erosion and environmental change, Importance and research needs, Catena, 50, 91-134, 2003.

Pollen, N. and Simon, A.: Estimating the mechanical effects of riparian vegetation on stream bank stability using a fiber bundle model, Water Resour. Res., 41, W07025, doi:10.1029/2004WR003801, 2005.

Ritter, A. and Muñoz-Carpena, R.: Performance evaluation of hydrological models: Statistical significance for reducing subjectivity in goodness-of-fit assessments, J. Hydrol., 480, 33-45, 2013.

Simon, A., Curini, A., Darby, S. E., and Langendoen, E. J.: Bank and near-bank processes in an incised channel, Geomorphology, 35, 193-217, 2000.

Simon, A., Pollen-Bankhead, N., and Thomas, R. E.: Development and application of a deterministic bank stability and toe erosion model for stream restoration, in: Stream Restoration in Dynamic Fluvial Systems: Scientific Approaches, Analyses, and Tools, AGU, Washington, DC, edited by: Simon, A., Bennett, S. J., and Castro, J. M., 453-474, 2011.

Sonneveld, B. and Keyzer, M.: Land under pressure: Soil conservation concerns and opportunities for Ethiopia, Land Deg. Dev., 14, 5-23, 2003.

Steenhuis, T. S., Tebebu, T. Y., Ayele, G. K., Guzman, C. D., Bayabil, H. K., Zegeye, A. D., Mogus, M., Dagnew, D. C., Stoof, C. R., and Tilahun, S. A.: Prioritizing landscape interventions in the Ethiopian highlands, Geophys. Res. Abstr., EGU General Assembly, May 2014, 16, EGU2014-16338, 2014.

Tamene, L., Park, S. J., Dikau, R., and Vlek, P. L. G.: Analysis of factors determining sediment yield variability in the highlands of northern Ethiopia, Geomorphology, 76, 76-91, 2006.

Tebebu, T. Y., Abiy, A. Z., Zegeye, A. D., Dahlke, H. E., Easton, Z. M., Tilahun, S. A., Collick, A. S., Kidnau, S., Moges, S., 
Dadgari, F., and Steenhuis, T. S.: Surface and subsurface flow effect on permanent gully formation and upland erosion near Lake Tana in the northern highlands of Ethiopia, Hydrol. Earth Syst. Sci., 14, 2207-2217, doi:10.5194/hess-14-2207-2010, 2010.

Tebebu, T. Y., Zegeye, A. D., Langendoen, E. J., Ayele, G. K., Tilahun, S. A., Ayala, E. K., and Steenhuis, T. S.: Arresting gully formation in the Ethiopian Highlands, in: Proceeding of rainwater management for resilient livelihoods in Ethiopia, ILRI, W. Mekuria, Nairobi, Kenya, 196-203, 2014.

Tebebu, T. Y., Steenhuis, T. S., Dagnew, D. C., Guzman, C. D., Bayabil, H. K., Zegeye, A. D., Collick, A. S., Langan, S., McAllister, C., Langendoen, E. J., Yitaferu, B., and Tilahun, S. A.: Improving efficacy of landscape interventions in the (sub) humid Ethiopian highlands by improved understanding of runoff processes, Front. Earth Sci., 3, 12 pp., doi:10.3389/feart.2015.00049, 2015.

Thorne, C. R.: Effects of Vegetation on Riverbank Erosion and Stability, Veg. Erosion, 125-144, 1990.

Tilahun, S. A., Guzman, C. D., Zegeye, A. D., Engda, T. A., Collick, A. S., Rimmer, A., and Steenhuis, T. S.: An efficient semi-distributed hillslope erosion model for the subhumid Ethiopian Highlands, Hydrol. Earth Syst. Sci., 17, 1051-1063, doi:10.5194/hess-17-1051-2013, 2013a.

Tilahun, S. A., Mukundan, R., Demisse, B. A., Engda, T. A., Guzman, C. D., Tarakegn, B. C., Easton, Z. M., Collick, A. S., Zegeye, A. D., Schneiderman, E. M., Parlange, J. Y., and Steenhuis, T. S.: A saturation excess erosion model, Am. Soc. Agr. Biol. Eng., 56, 681-695, doi:10.13031/2013.42675, 2013b.

Valentin, C., Poesen, J., and Li, Y.: Gully Erosion: Impacts, Factors and Control, Catena, 63, 132-153, 2005.

Vandekerckhove, L., Poesen, J., and Govers, G.: Medium-term gully headcut retreat rates in southeast Spain determined from aerial photographs and ground measurements, Catena, 50, 329352, 2003.
Vanmaercke, M., Poesen, J., Van Mele, B., Demuzere, M., Bruynseels, A., Golosov, V., Bezerra, J. F. R., Bolysov, S., Dvinskih, A., and Frankl, A.: How fast do gully headcuts retreat?, Earth-Sci. Rev., 154, 336-355, doi:10.1016/j.earscirev.2016.01.009, 2016.

Zegeye, A. D., Steenhuis, T. S., Blake, R. W., Kidnau, S., Collick, A. S., and Dadgari, F.: Assessment of soil erosion processes and farmer perception of land conservation in Debre Mewi watershed near Lake Tana, Ethiopia, Ecohydrol. Hydrobiol., 10, 297-306, 2010.

Zegeye, A. D., Amare, S. D., Tilahun, S. A., Langendoen, E. J., Dagnew, D. C., Guzman, C. D., Tebebu, T. Y., and Steenhuis, T. S.: Gully development processes in the Ethiopian highlands, in: Proceedings of the second International Conference on the Advancements in Science and Technology (ICAST), Bahir Dar University, 220-229, 2014.

Zegeye, A. D., Amare, S. D., Tilahun, S. A., Dagnew, D. C., Addisie, M. B., Ayele, G. K., Guzman, C. D., Langendoen, E. J., Tebebu, T. Y., Kassie, T. A., Tilahun, S. A., and Steenhuis, T. S.: Sediment production from gully erosion in the (sub) humid Ethiopian highlands: The Debre Mawi watershed, TROPILAKES general assembly, Bahir Dar, Ethiopia, 23-29 September 2015 .

Zegeye, A. D., Amare, S. D., Tilahun, S. A., Steenhuis, T. S., and Langendoen, E. J.: Calibration and validation of the CONCEPTS computer model for predicting gully erosion and control in the sub-humid Ethiopian Highlands: The Debre Mawi watershed, in: Proceedings of the 4th International Conference on the Advancements in Science and Technology (ICAST), Bahir Dar University, Ethiopia, 17-18 June 2016, 9-21, 2016. 